\title{
ПРОФЕСІЯ МАНЕКЕННИКА В УКРАЇНІ: РАДЯНСЬКИЙ ПЕРІОД І СУЧАСНІСТЬ
}

\begin{abstract}
Метою статті є дослідження особливості в роботі чоловіків-манекенників в радянській та сучасній Украӥні, аналіз їхнього місия та внеску в загальний розвиток дизайну, а також впливу на творчість українських художників-модельєрів сьогодення. Методика. Методологічною базою дослідження є системний підхід, а також методи порівняльно-історичного та мистецтвознавчого аналізу. Результати. У рамках даного дослідження було проведено три інтерв'ю з відомими українськими чоловіками-манекенниками. Усі три манекенника належать до різних поколінь і стали свідками різних етапів модного життя в краӥні. Їхні образи нам видаються найбільш характерними та уособлюють естетичні ідеали свого часу. Творчі шляхи В. Швеия, С. Чудовського та М. Горлова стають показовими для всіх, хто займався та займається такою рідкою для чоловіків професією, як демонстрант моделей одягу. У процесі дослідження виявлено, щио, не дивлячись на зміну культурного контексту, суть професії майже не змінилася: демонстрація ідей дизайнерів, втілення образної складової частини колекиії та буття порадниками і першими споживачами одягу. Наукова новизна полягає у визначенні особливостей роботи манекенників у радянській та сучасній Украӥні як одних із ключових дійових осіб модного процесу, щзо демонструють ідеї художників-модельєрів, а їхні образні видозміни впливають на загальний естетичний розвиток у країні та у світі. Практична значущістьь полягає в тому, щзо подані у статті матеріали, фрагменти інтерв'ю, їх аналіз та узагальнення можуть бути використані в наступних дослідженнях, пов'язаних із демонстрацією колекиій на подіумі, роботою манекенників та дизайнерів та дослідженням чоловічої естетики XX - XXI століття, щзо може стати основою для подальшого впровадження в авторських творчих розробках.
\end{abstract}

Ключові слова: манекенники, дизайн в Україні, естетика, чоловіча мода, демонстрація одягу.

Iryna CHUBOTINA, orcid.org/0000-0001-8436-0086 Graduate Student at the Department of Fashion Design Kyiv National University of Culture and Arts (Kyiv, Ukraine)iri-s83@outlook.com

\section{PROFESSION OF MALE-MANNEQUIN IN UKRAINE: THE SOVIET PERIOD AND THE PRESENT DAYS}

The purpose of the article is to study features of work of male mannequins in Soviet and modern Ukraine, to analyze their place and contribution to design development, as well as their impact on the work of Ukrainian fashion designers today. Methodology. The methodological basis of the study is a systematic approach, as well as methods of comparative historical and art analysis. Results. Within this study, there were held three interviews with famous Ukrainian male mannequins. All three male mannequins belong to different generations and have witnessed different stages of fashion life in the country. Their images seem the most typical to us and embody the aesthetic ideals of their time. The creative paths of V. Shvets, S. Chudovsky and M. Gorlov become indicative for all those who have been and are engaged in such a rare profession for men as a demonstrator of clothing models. The study showed that despite the changing cultural context, the essence of the profession has not changed: the demonstration of ideas of designers, the embodiment of the figurative component of the collection and becoming advisers and first consumers of the models. The scientific novelty is definition of the features of male-mannequins work in Soviet and modern Ukraine, as one of the key actors of the fashion process, who demonstrate ideas of fashion designers, whereas their figurative changes affect the overall aesthetic development in the country and in the world. The practical significance is that the materials presented in the article, excerpts from interviews, their analysis and generalization can be used in further research on demonstration of collections on the catwalk, work of models and designers and the study of male aesthetics of XX-XXI centuries. It can become the basis for further implementation in the author's creative developments.

Key words: male-mannequins, design in Ukraine, aesthetics, men's fashion, clothing demonstration. 
Постановка проблеми. Мода залишається одним із тих поодиноких прикладів, коли, використовуючи гендерну термінологію, маскулінність беззаперечно капітулює перед фемінністю. На тлі боротьби за гендерну рівність, де в статусі «жертви» завжди опинялися жінки, царина «моди» завжди була жіночим форпостом, замахи на який тільки зміцнювало позиції. Традиційні патріархальні настанови більшості чоловіків, радянська і пострадянська косність спровокували насторожене відношення до чоловічої моди як до маргінальної примхи вузької групи чоловіків. Особливо це стосується такої невід'ємної частини модного процесу, як демонстрація одягу на подіумі. Дана стаття базується на інтерв'ю, які ми взяли у трьох відомих українських манекенників Віктора Швеця, Сергія Чудовського та Марселя Горлова, що належать до трьох різних поколінь i були свідками різних етапів української моди.

Мета статті - на основі взятих інтерв'ю, перегляду ілюстративних джерел, також на аналізі культурного та історичного контексту виявити особливості розвитку чоловічої модельної професії в Україні, дослідити їі основні етапи становлення; виявити тенденції подальшого розвитку в нас у країні та світі.

Аналіз попередніх досліджень. Сьогодні питання демонстрації одягу чоловіками-манекенниками в Україні, як і більшість питань, що стосуються чоловічої моди, не одержали розгорнутого висвітлення в наукових працях. Здебільшого згадки про цю професію та іiї історичний контекст можна знайти у «глянцевих» виданнях, хоча майже всі вони стосуються світових «зірок подіуму» (Okwodu, 2016). Поодинокі свідоцтва про працю радянського періоду чоловіків-моделей можна зустріти у працях О. Васильєва (Васильев, 2007), А. Щипакиної (Щипакина, 2009). Було видано кілька книг, присвячених праці моделей, проте, закономірно, здебільшого вони досліджують жіночу сторону професії (Степура, 2000, Медников и др., 2003). Відображення в радянському кінематографі професії демонстраторів моделей одягу досліджувала Т. Дашкова (Дашкова, 2017), а місце моделей у фото-мистецтві за часів відлиги окреслила О. Вікуліна (Викулина, 2011). Дотичними до нашого дослідження виявилися статті I. Кона та О. Барабан, що увійшли до збірці «О муже(N)ственности», присвячені чоловічій естетиці на радянських та пострадянських теренах (Ушакин, 2002). Суттєвими для розуміння еволюцій української у цей період стали роботи Г. Кокоріної та Т. Ніколаєвої (Ніколаєва, Кокоріна, 2018).
Виклад основного матеріалу. Для початку треба сказати, що чоловіча мода в Україні - це дуже не проста тема, відносини «чоловік - модний показ» все ще викликає питання. Тим більше якщо йдеться про чоловіків, які безпосередньо $\epsilon$ учасниками модного процесу. I якщо професії модельєрів, фешн-фотографів, режисерів-постановників традиційно обіймали чоловіки, то професія «манекенник» завжди була феноменом. Основна причина - в упередженому ставленні до чоловічої естетики, що стосується не тільки моди, а й повсякденних життєвих практик. І. Кон, відомий вчений-соціолог, каже про це: «Страх видатися жіночним знаходить своє відображення і в буденних критеріях чоловічої привабливості. «Справжній чоловік» повинен бути грубуватим i позбавленим прагнення подобатися. Красивий, витончений чоловік часто викликає підозри в жіночності, розніженості, дендізмі, гомосексуалізмі» (Ушакин, 2002: 46-47).

У ході розгляду даної теми ми не можемо обійти питання про різні грані чоловічої краси, що залежно від історичного контексту змінювали один одного. Так, І. Кон, змальовуючи типи чоловічого тіла, що зображувалось, виділяє такі модальності: активно-героїчне, жіночно-андрогинне, страждаюче, хлопчаче-юнацьке, атлетичне і фашистське (Ушакин, 2002: 9). Усі ці подачі чоловічої зовнішності в тому чи іншому ступені проявлялися як у класичному мистецтві, так і в новітній історії. Усі ці модальності можна екстраполювати і на історію вітчизняної моди XX - початку XXI століть. Із початку відбудови нової радянської держави за естетичний ідеал було взято активногероїчний канон зображення чоловічого тіла як «класична модель гегемонії маскулінності, персоніфікація чоловічої сили, влади і могутності» (Ушакин, 2002: 59). Але треба розуміти, що, на відміну від грецьких атлетів або мікеланджелівських героїв, радянський образ мужності виключав естетизацію, він не міг бути «об' єктом краси», який можна було б споглядати. Радянський герой при всій своїй монументальності був завжди в дії, був активний. У радянській скульптурі гіперболізоване тіло робочого чи воєнного гранично близько до фашистського ідеалу, що було «антитезою жіночності і гомосексуальності, які як правило приписувалися шкідливим інородцям. Ця ідеологія, яка ставила «жорстке» чоловіче тіло принципово вище «м'якого» жіночого тіла, мала сильний мілітаристський i націоналістичний присмак, що досяг кульмінації в неокласицизмі німецького та італійського фашизму» (Ушакин, 2002: 64). I все ж сувора дійсність 1920-х років 
підкріплена інтенсивною пропагандою, вселяла людям ідею аскетизму та бережливості, а також сугубо негативне відношення до буржуазної моди. Із приходом до влади Й. Сталіна риторика влади дещо змінюється. Нова влада тяжіє до більш помпезного стилю, що головує впродовж більше тридцяти років. Воєнний час вносить нововведення у візуалізацію маскулінності і підіймає вже забутий культ «страждаючого» тіла - пораненого солдата, літньої людини і т. п., яке до цього із іншими сенсами активно використовувалося у християнській тематиці. Ці зображення стають знаковими в радянській міфології, проте основними культурними героями залишаються оптимістичні образи повних сил чоловіків. Такі типажі були представлені на сторінках радянських модних видань 1950-х: абсолютно статичні пози, беземоційні обличчя, які були щедре відретушовані у стилі довоєнного кінематографу, з м'яким округлим абрисом і тонкою чіткою лінією брів та губ, що контрастують із важким монументальним силуетом одягу. Ці журнальні образи - була «вітрина» радянської моди, рядові громадяни задовольнялися скромним асортиментом радянських магазинів, що виправдовувався вторинним значенням моди для радянської людини. Насправді, як пише О. Барабан, «часто змінювати одяг було, з одного боку, непристойно, а з іншого - недоступно. Ідеологічним підгрунтям негативного ставлення до одягу було те, що, турбота про себе в радянський час більше передбачала турботу про славнозвісне «моральне обличчя», ніж про свою зовнішність. (...) Однак якщо жіноча мода все ж існувала, то чоловік і мода були поняттями практично несумісними» (Ушакин, 2002: 139). Деякі зміни починаються з настанням так званої «відлиги», короткого періоду в радянській історії, що прийшовся на правління М. Хрущова, що характеризувався частковим розвінчання сталінського культу i підвищеною цікавістю до західної культури. При цьому радянська мода починає демонструватися за кордоном і стає «ідеологічною зброєю, площиною для змагання із закордонними країнами» (Викулина, 2011: 28). Журнали того часу починають публікувати «розгорнуті репортажі 3 магазинів і будинків мод, а також рекламні фотографії, в яких задіяні професійні моделі» (Викулина, 2011: 28). Але в більшості це стосувалося жінок, тому що чоловік, якщо не рахувати знімки офіційних та відомих постатей, поставав насамперед як людина праці.

При цьому подвійному відношенні до моди та конс'юмеризму в цілому у цей час іде повним ходом становлення радянської легкої промисло- вості, яка повинна була на даному етапі складати конкуренцію західній. Особливо важливим було саме розкішне демонстрування їх витворів, і тому особливо високо цінувалися вродливі моделі та манекенники. Про структуру радянських будинків моделей було цікаво сказано у виданні «Професія: модель»: «Елітні будинки моделей, що ззовні представляли єдиний організм, на справді являли собою два майже не пересічних рівня. Привілейовану касту становили співробітники, що працювали на «престиж країни». Коли йшлося про престиж, у СРСР не скупилися. Майбутніх «виїзних» моделей розшукували як принц - Попелюшку» (Медников и др., 2003: 8).

Розкріпачення 1960-1970-х років у західній Європі та США продукує новий тип чоловічої краси, із андрогінними характеристиками, які стосувалися скоріше зовнішніх атрибутів: видовжені стрижки, астенічна статура, яку підкреслював прилеглий силует і високі підбори. При цьому образи були не надто рафінованими, скоріше переважали юнацькі риси. Зрозуміло, що в Радянському союзі нові віяння західної культури зустрічали жорстку відсіч, із часів «стиляг» 1950-х років ніхто так не висміювався як вітчизняні «діти-квіти» 3 вещизмом та ідолопоклонством перед Заходом. I все ж «залізна завіса» до середини 1960-х була вже не настільки вакуумована, а це означає, що і українську дійсність наповнювали нові естетичні реалії. Окрім цього, завдяки неослабному протистоянню із західним світом відбувається реструктуризація легкої промисловості. У зв'язку із цим змінюється відношення і до демонстрації продукції. Журнальна ілюстрація все більше поступається фотографії, i свої обриси набуває нова професія манекенника. У Радянському союзі слово «модель» не вживали, замість цього використовували вираз «демонстратор моделей одягу». Так, одним із найбільш уславлених, «унікальних» демонстраторів в Україні $\epsilon$ на сьогодні Віктор Швець, актор і викладач, який присвятив українській моді більш ніж 50 років свого життя, прийшовши у професію манекенника в кінці 1960-х. Для нашого дослідження ми зустрілися 18 грудня 2019 року з Віктором Євдокимовичем і провели у приміщенні Київського національного університету театру, кіно і телебачення імені І.К. Карпенка-Карого вельми цікаву бесіду. Відомий манекенник розповів, як саме він опинився в модній сфері. За часи навчання на акторському факультеті Віктор Євдокимович брів участь у зйомках в Ялті, куди на чергові покази приїхав Київський будинок моделей (КБМО). Єдиний на той час демонстратор отримав тоді травму, 
і співробітники шукали йому заміну та звернулися до знімальної групи, що шукають молоду людину відповідного росту та зовнішності. I дуже скоро він стає на українську подіумі «на расхват». Елегантність, яку привносив Віктор Свдокимович у демонстрацію одягу, багато в чому була наслідком акторської професії (рис. 1).

Звичка 3 гідністю представляти вихідний класичний гардероб у радянському суспільстві була фактично втрачена. Ідеалом на той час став для манекенника французький актор Жан Маре. Витонченість і грацію рухів в елегантному костюмі Віктор Євдокимович зберіг до останніх своїх дефіле, що прийшлися вже на початок 2000 -х років, тим самим знаходячись у центрі української чоловічої моди майже пів-століття. Цікаво, що на Вікторі Свдокимовичі навіть випробували експериментальний манекен: «Вони змастили мене якимось жиром. Потім брали туалетний папір і обмотували. Обернули, змастили клеєм, обернули, змастили клеєм. При цьому я стою та не рухаюсь. Щоб воно все висохло - вмикали духовку. І це так я стояв - висихав, щоб вони могли зробити. I в них дійсно вийшов манекен». На той час чоловіків-манекенників були одиниці. Але незважаючи на свої успіхи та затребуваність, Віктору Євдокимовичу доводилося тривалий час приховувати свою нову професію від сім’ї та знайомих: «Ніхто з сім’ї не знав. Спробуй, розкажи дружині!... А вона потім ще комусь, і піде... «А в тебе чоловік у моделях ходить!». Віктор Свдокимович пригадує, що чоловікам виходити на подіум тоді не було в пошані, на відміну від жінок: «Для дівчат виходити на подіум - це була шикарна реклама. Якщо ти з'явилася в журналі на кшталт «Краса і мода», тебе всюди кличуть, запрошують на зйомки, якісь вручення, де потрібні відомі обличчя. Виходили дівчата, і оголошували «Модель Київського будинку моделей!...» Для чоловіків такого ніколи не було, і я завжди намагався уникнути від такої популярності».

На той час однією із ключових фігур в 1960-1970-х pр. у модній сфері в Україні був В. У. Несміян. Володимір Уллянович на початку своєї кар'єри був чоловічим майстром у швейній артілі, потім займається жіночим моделюванням у КБМО, а після у 1969 році починає працювати художнім керівником у Республіканському Будинку моделей Міністерства побутового обслуговування населення УРСР, згодом він засновує перший в Україні глянцевий журнал «Краса і мода». Особливу роль він зіграв на межі 1960-1970-х і для модельної професії. Як пише відомий історик моди Г. Кокоріна: «Ще на початку 60 -х років, коли до Києва приїздили італійці з показом колекції одягу «для простих людей», В. У. Несміян звернув увагу на структуру показу, якість музичного супроводу та пластику рухів манекенниць. (...) Для підготовки показів в 1970-1980 рр. запрошували відомих композиторів, зокрема Леоніда Сухорукова, який монтував фрагменти музичного супроводу. Балетмейстер Олексій Біткіне режисирував покази, опрацьовуючи малюнок виходів і «розводку» демонстрантів. У результаті покази перетворювалися

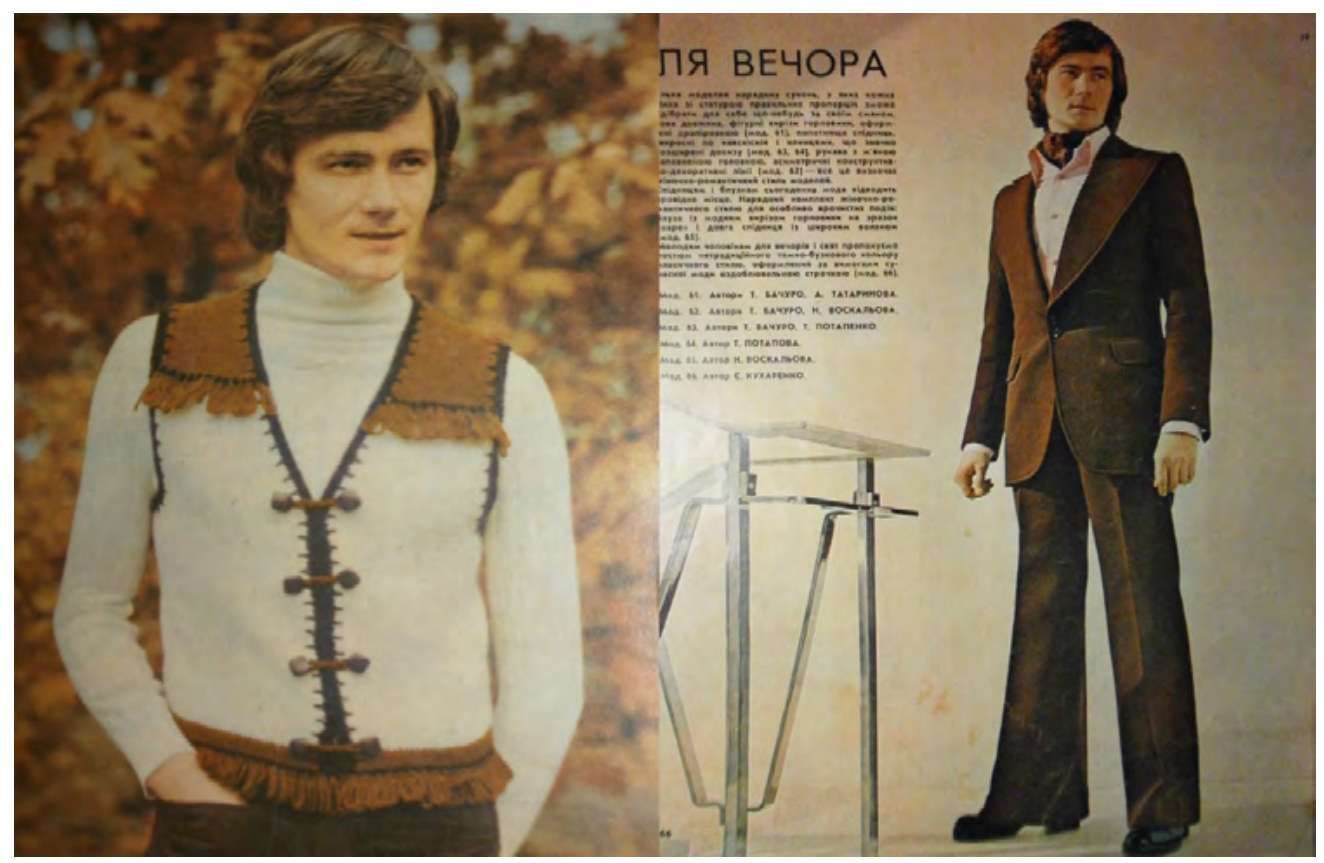

Рис. 1. В. Швець, журнал «Краса і мода», поч. 1970-х рр. 
в яскраві видовищні вистави, які готували раз на рік і демонстрували по Україні, всьому Радянському Союзу та за кордоном». (Ніколаєва, Кокоріна, 2018: 136). Про подібні експерименти пригадує і Віктор Євдокимович : «Покази у Будинку моделей побуту, що розташований був на вулиці Артема, режисував постановник, актор із театру оперети, Ігор Афанасьєв. Тоді зробили один із перших постанов на подіумі. Не просто показ, а саме спектакль. Яким чином? Починалось: ранок, на сцені було ліжко, ми прокидалися, я вдягав піжаму, потім ми 3 моєю «дружиною» виходили до сніданку, потім перевдягалися й шли на роботу, після роботи йшли кудись і увечері йшли до ресторану. Тобто це був такий міні-спектакль із музикою, з рухами, з текстом, там все було».

Після набуття Незалежності для української моди настали важкі часи, закривалися фабрики, модельєри та конструктори шукали можливості заробляти, змінювали професії. Костюми від легендарного на той час майстра Михайла Вороніна підроблювали й продавали на ринку. Віктор Євдокимович із гіркотою пригадує той час: «Підробляли лейби й пускали у продаж! Я приходив до Вороніна, а він аж плакав : «Під моїм ім'ям і таке барахло!» Я підходив тоді до продавців, вдягав і казав: «Майте ж совість!». Але бренду Voronin тоді вдалося вистояти, з 1991 Михайло Львович організував підприємство «Михайло Воронін Відень - Париж», а з 1994 - ВАТ КШ «Желань», на яких шилися моделі, і продовжувалася демонстрація колекцій. На черговому показі, приуроченому до відкриття магазина Вороніна в Запоріжжі, Віктор Швець падає із двометрової висоти та скалічує собі ноги. Про продовження кар'єри на подіумі на могло бути й мови, і Віктор Євдокимович вирішує повністю присвятити себе акторській професії та викладацькій діяльності. Але у скорому часі стає зрозуміло, що Віктор Євдокимович став просто незамінним на подіумі. I через наполягання Михайла Вороніна він відновлює форму і знову демонструє моделі (Назаренко, 2005). Вигідно вирізняючись від більшості юнаків-моделей своєю аристократичною грацією і природнім артистизмом, Віктор Євдокимович залишався беззмінним «обличчям» бренду Voronin і залишає подіум тільки зі смертю головного чоловічого кутюр'є України у 2012 році (рис. 2).

Весь час, доки Віктор Свдокимович був головною «дієвою особою» української моди, йому доводилося приймати для себе не лише «парадний бік» професії - напружена праця та найчастіше негативне ставлення оточуючих - але при всьому цьому він залишається небайдужим до модельної професії. В інтерв'ю він підмічає, яка велика різниця між естетичними ідеалами минулого і сучасності: «Ось нинішні моделі, я бачу, без чоловічої основи. Якісь «хлюпіки», їм би 3 віялами ходити та очі фарбувати... А в минулому скоріше «мужички» в моді були».
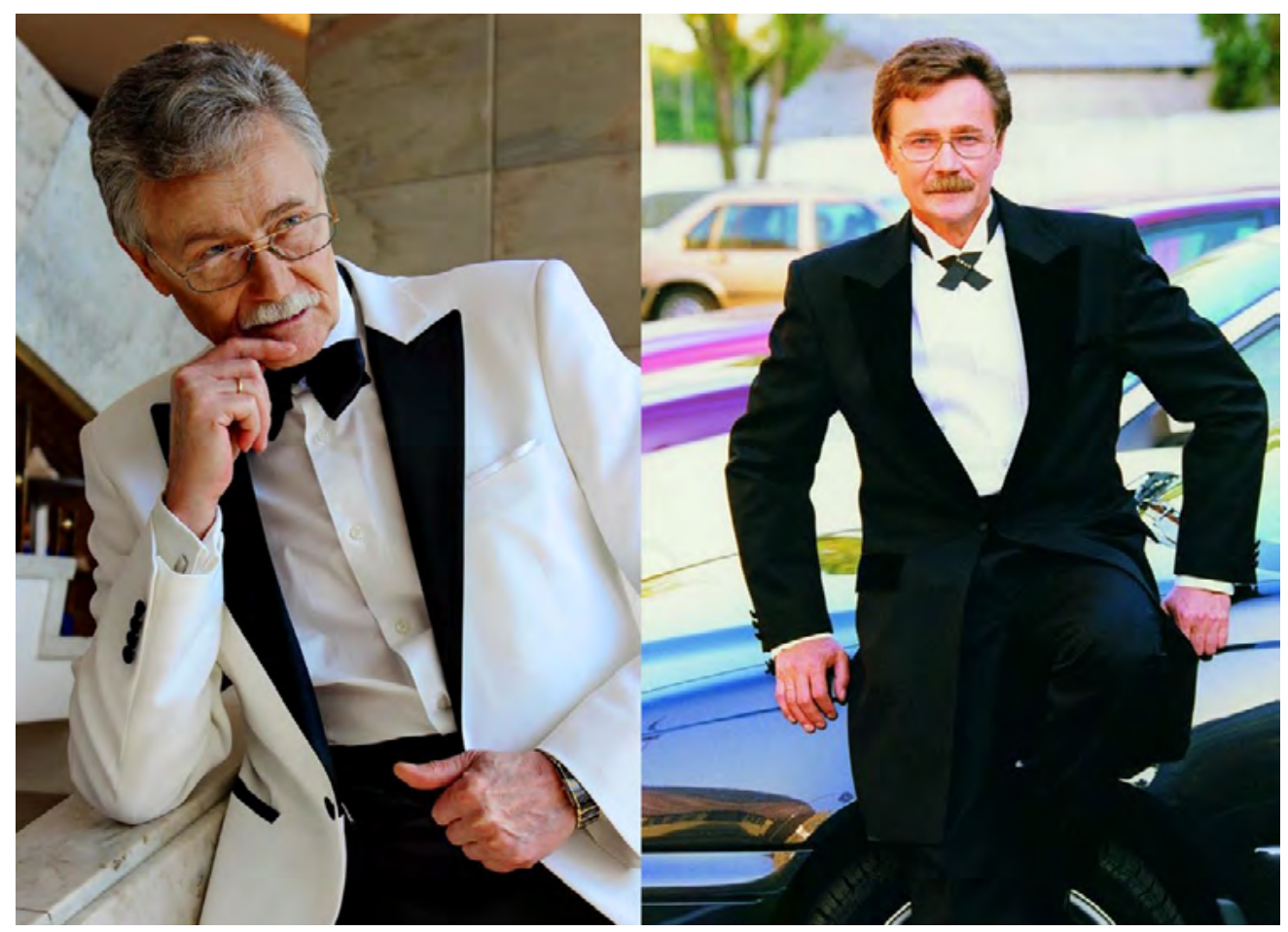

Рис. 2 В. Швець демонструє моделі М. Л. Вороніна, кін. 1990-х - поч. 2000-х рр. 
На початку 1990-х із тотальною переоцінкою цінностей змінюється і ставлення до професії манекенників, яка змінює дислокацію з будинків моделей до модельних агентств. Рекламної продукції стає в рази більше, зйомки для українських видань квапляться підлаштуватися під нові віяння: стають яскравішими та відвертішими. Стають затребуваними нові обличчя, в чоловічій моді брутальність, накачані тіла. Активно пропагується новий канон краси - спортивне тіло. «На відміну від героїчного тіла, гармонічні лінії якого можуть бути вродженими, атлетичне тіло завжди - зроблене, воно завжди персоніфікує типово маскулінний потяг досягнення» (Ушакин, 2002: 63). Нову естетику демонструють А. Шварцнегrep та С. Сталлоне 3 голлівудських бойовиків 1980-1990 років, що розповсюджувались по відеопрокатам та, з часом, заповнили новостворене українське телебачення. Окрім того, стає популярним бодібілдинг, феномен якого, на відміну від інших спортивних активностей, саме в «оформленні» власної фігури заради неї самої, як відмічає О. Вайнштейн, «тіло виступає як друга природа, яку спортсмен «оброблює», «окультурює», ліпить» (Вайнштейн, 2005: 578). Також мистецтвознавець конкретизує, що у сучасній культурі «вельми бідно розроблена мова чоловічої тілесності», через що де-які бодибілдери «запозичують для своїх виступів арсенал виконавців стриптизу». I багато манекенників 1990-х приходять саме із бодібілдингу, чи зі стриптизу, близькість до якого модельного бізнесу, робила професію моделей гранично двозначною. При цьому зали- шалася в тренді і класична «аполлонівська» краса, подібна до архетипу «справжнього чоловіка», що склався ще у 1930-і роки - «блондин із чисто поголеним обличчям і холодними блакитними очима» (Вайнштейн, 2005: 563). Саме в цей час слава приходить до Сергія Чудовського, що був представником саме такого типу зовнішності.

Один із найвідоміших українських манекенників, лауреат багатьох конкурсів краси, режисер-постановник модних показів, викладач Київського національного університету технології та дизайну, Сергій застав кінець радянської епохи, його кар'єра бурхливо розвивалася у 1990-і, такі складні для вітчизняної моди часи (рис. 3).

Ми провели бесіду із Сергієм вересня 2018 року у приміщенні Київського національного університету технології та дизайну, де зараз він викладає. Сергій розповів нам про початок своєї кар'єри манекенника: «Будинки моделей вішали об'яви «Потрібні демонстратори моделей одягу, такі-то розміри, такого-то зросту». Я попав саме за таким оголошенням. (...) I в якийсь момент я став багато заробляти, тому що влаштувався всюди, де міг оформитися: в експериментальні цеха, в Молодіжний будинок одягу, Центр розвитку моди, КБМО». Довгий час працюючи в цій сфері, Сергій аналізує модний потік 1980-1990 років: «Цей одяг в основному створювали жінки. Не відчуваючи чоловічу природу, не маючи чоловічого початку, вони створювали одяг як відчували жінки. I це було або квадратне щось, або взагалі не чоловіче, тобто додавали якісь жіночі елементи намагалися створити

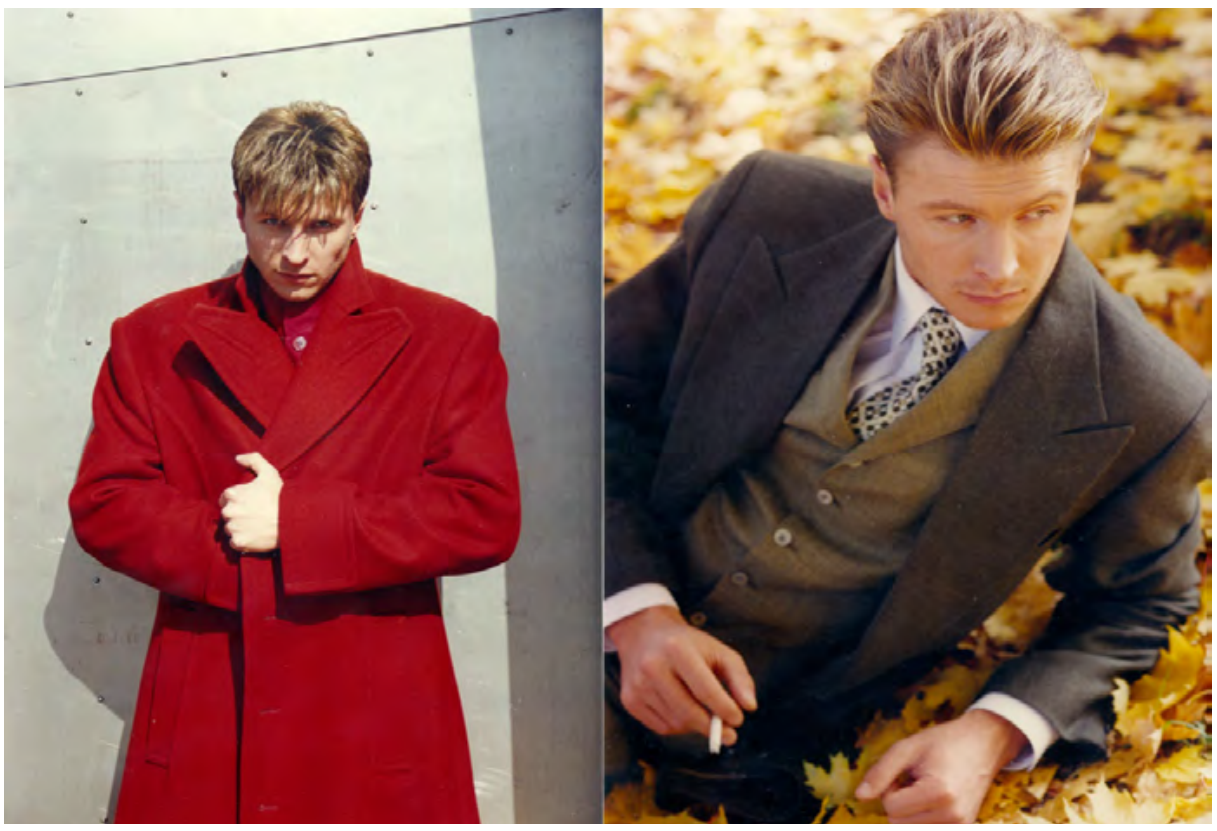

Рис. 3. С. Чудовський представляс моделі М. Л. Вороніна, 1990-і роки 
образ ніби то чоловічій.(..) Що казати, якщо мені давали светр жіночий, і казали: «Вдягни, а рукава, нічого що закороткі, ти їх загорни!». Про сучасну моду Сергій відгукується ще більш категорично: «У нас в Україні немає індустрії чоловічої моди, отож і професія манекенника не потрібна. Люди до мене приходять у модельну школу, вчаться, але їх основна ціль - виїхати за кордон». Сергій Чудовський у своїх роздумах про професію дуже точно визначає роль моделі не просто як фізичної оболонки, а як натхненника для творця, або як першого «споживача» $\mathrm{i}$ колеги по творчості, традиція чого, вже, на жаль відходить: «Зараз немає розуміння, що таке чоловік, на якого потрібно пошити одяг. «Посадити» на нього, подивитися як він рухається, спитати, як він себе відчуває, чи зручно йому? Манекен про це не розповість. А Воронін завжди задавав ці питання. I я відповідав. I Мепену (Герц Мойсейович Мепен, (1921-2004), художній керівник КБМО, прим. авт.) я казав, що відчуваю. Хто як не манекенник надихає маестро?» У роздумах Сергія чоловіча мода невід'ємна від «фізичної краси» та гігієни, які розуміються як показники культури суспільства в цілому: «Ні митися, ні голитися, ні гарно виглядати, ані приводити до ладу волосся, слідкувати за взуттям, тренуватися та слідкувати за своїм тілом - люди не вміють. В Європі є культ здорового, красивого джентльмена, денді. У нашій країні цього немає, і це загальна проблема. Люди повинні думати про це, й доносити іншим, адже наші думки можуть багато що змінити. Це важливо, тому що хочеться бути в оточенні красивих людей».

Наближаючись до сучасного сприйняття професії, очевидною стає зміна чоловічого ідеалу від гротескно-брутального 1990 років до більш м'якого образу 2000-х, так званого «genderbending» - змішанні чоловічого та жіночого. Так, неможливо оминути питання гендерних зсувів у цей період. Ці зміни в бік сексуального розкріпачення, та особливо в бік змішування чоловічого та жіночого у нашому відносно патріархальному суспільстві викликали настороженість у консервативної публіки. «Зміна чоловічого тілесного канону - це не слідство зловісної «гомосексуалізації» культури і суспільства, а один з аспектів довгострокового глобального процесу перебудови гендерних стереотипів» - доводить I. Кон, (Ушакин, 2002: 78). 3'являється новий стандарт чоловічої краси - так звана андрогінна краса. На вітчизняному подіумі фактично зникає класичний, «респектабельний» гардероб, який традиційно представлявся манекенниками «героїчної» зовнішності. На сучасному етапі модельні агенції знаходяться в пошуку не просто красивих обличь, а унікальної зовнішності. При цьому атлетична зовнішність, типажу «брутальних мачо» все ще актуальна на українському подіумі, дуже часто «розкачаних» моделей беруть у найбільш ради-

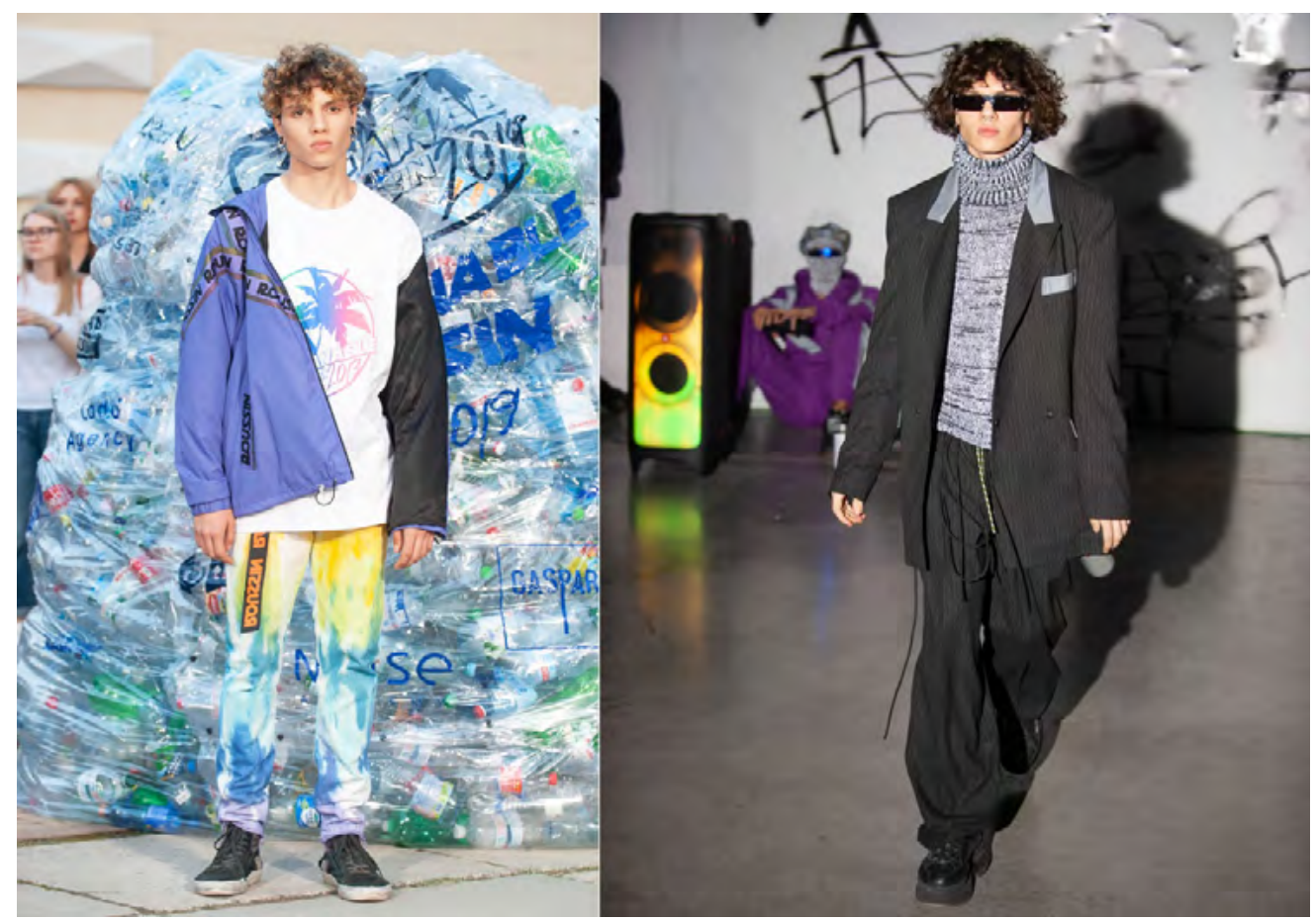

Рис. 4. М. Горлов, Ukrainian Fashion Week, ROUSSIN SS2019-20, FW20-21, фото: В. Босак 
кальні авангардні колекції, де чоловіки постають iз яскравим макіяжем, на високих підборах і т. д. В останній час така екстравагантність сусідить із хлопчачо-юнацькою красою. На подіумі затребувані хлопці з унікальними особливостями: лисі, або з волоссям до плечей, з татуюваннями, пірсингом. Одним із найбільш успішних представників нової української модельної школи стає Марсель Горлов, родом із творчої родини, його батько i дід - професійні музиканти, і сам Марсель активно бере участь у різних музичних проектах. Володіючи яскравою зовнішністю, такою, що одразу запам'ятовується (великі риси обличчя, кучеряве волосся), Марсель бере участь практично у всіх чоловічих і «змішаних» показах з 2018 року (рис. 4).

При цьому він не розглядає професію моделі як самодостатню професію, а скоріше як базу для подальших творчих пошуків: «Не хочу заганяти себе в рамки, що я модель, або манекенник. Я б назвав це просто «артист», людина мистецтва», розповів нам манекенник 2 лютого 2020 після репетиції показу у приміщенні Мистецького арсеналу на зимовому Українському Тижні Моди. Не дивлячись на великі еволюції в чоловічій моді, наш респондент констатує, що це залишається як і раніше жіночої спеціальністю «Хлопців просто менше, ними менше займаються. Звичайно, знімаються compaign, $\epsilon$ чоловічі fashion week, але все це не так давно почалося». Марсель відверто зізнається, що одна 3 основних проблем цієї професії - це відсутність належного фінансування, при тому, що робота забирає багато сил i часу: «Мінуси - очікування, ти продаєш своє час за певний коефіцієнт грошей, і це займає надто багато часу». При цьому найбільша віддачу від своєї професії Марсель, як і його колеги, бачить у співпраці і «со-творчості» манекенника і модельєра: «С «задаваки», які не дають проявляти творчий потенціал самої моделі, особливо молоді.
Вони прислухаються навіть у плані стилістики до порад манекенником. Коли ти звертаєшся до них і кажеш, що так і так буде краще. Вони прислухаються, намагаються, і дійсно, виходить інший результат». Будучи затребуваним не тільки в Україні, манекенник вельми критично налаштований на таку бажану роботу за кордоном: «Я брав участь у campaign Honda, це було в Шанхаї. Працювати в Китаї дуже дивно, тому що сильно відрізняється менталітет, дуже специфічні люди. I ставлення до моделей як шматків м'яса, не у всіх, звичайно, агентствах, але в більшості». Цікаво, що, не дивлячись на «тектонічні» зрушення в області чоловічої естетики, Марсель Горлов не дуже любить розповідати оточуючим про свою професію. Але будучи із творчого середовища, він знаходить відгук у своїх рідних: «Сім'я позитивно реагує. А яка альтернатива: краще барменом працювати? Або працювати з Honda, або Asics?» Вже після нашого інтерв'ю М. Горлов взяв участь у ще одному вельми цікавому проекті від дизайнерського бренду одягу $\mathrm{FINCH}$, що в партнерстві 3 брендом окулярів Casta презентував колекцію 3 використанням AR-технологій та 3D-друку, де Марсель Горлов виступив одним із прототипів фігур для 3D-друку (Finch + Casta Eyewear, 2020).

Висновки. Так, не дивлячись на зміну культурного контексту, багато в роботі чоловіківманекенником в Україні залишається незмінним. Не дивлячись на те, що у країні функціонують безліч професійних модельних шкіл і що наші манекенники працюють у всьому світу, професія, як і раніше, резонансна в сучасному українському суспільстві та також затиснута в рамки патріархального менталітету і естетичної скутості, які роблять їі гранично складної для чоловіків. Вона стає контрапунктом гендерної чоловічої ідентичності, складних реалій вітчизняної і соціальної моди щодо чоловічої естетики.

\section{СПИСОК ВИКОРИСТАНИХ ДЖЕРЕЛ}

1. Вайнштейн О. Б. Денди: мода, литература, стиль жизни. Москва : Новое литературное обозрение, 2005.640 с.

2. Васильев А. А. Русская мода. 150 лет в фотографиях. Москва : Слово, 2007. 448 с.

3. Викулина Е. Репрезентация гендера в советской фотографии «оттепели». Современный дискурс-анализ. Электронный журнал. 2011. № 5. С. 21-34.

4. Дашкова Т. Неслужебная походка: дефиле в советских фильмах оттепели и застоя. Теория моды. 2017. № 4(46). URL : https://www.nlobooks.ru/magazines/teoriya_mody/46_tm_4_2017/article/19304 (дата звернення: 23.07. 2020).

5. Медников Я., Литовченко В., Шербань Л. Профессия: модель. Киев : ЛМУ, 2003. С. 112.

6. Назаренко М. Демонстрант одежды Виктор ШВЕЦ: «Среди девочек-моделей я был, как петух в курятнике, но ни разу этим не воспользовался». Бульвар Гордона. № 29(29). 2005. URL : http://bulvar.com.ua/gazeta/archive/ s29_2770/1637.html (дата звернення: 22. 09.2019).

7. Ніколаєва Т. В., Кокоріна Г. В. Творча біографія дизайнера Володимира Несміяна: між пам'яттю та свободою. Art and Design. 2018. № 3. С. 132-144. URL : http://nbuv.gov.ua/UJRN/artges_2018_3_14.

8. Степура М. Как стать моделью : учебное пособие. Р.-на Дону : Феникс, 2000. 384 с.

9. Омуже(N)ственности: Сборник статей. Сост. Сергей Ушакин. Москва:Новоелитературное обозрение, 2002.702 с.

10. Щипакина А. Мода в СССР. Советский Кузнецкий. Москва : Слово, 2009. 392 c. ISBN: 978-5-387-00119-2. 
11. Finch + Casta Eyewear презентували перший показ у доповненій реальності. Ukrainian Fashion Week. 02 лютого 2020. URL : http://fashionweek.ua/news/ukrainian/finch-casta-eyewear-day-2 (дата звернення: 11.09. 2020).

12. Okwodu J. 40 Years of Male Models: Tyson Beckford, John Pearson, Tony Spinelli, and Co. Remember Their Glory Days : Vogue.com, 2016. URL: https://www.vogue.com/article/male-modeling-icons-40-уеаrs (дата звернення: 20.06. 2020).

\section{REFERENCES}

1. Vainshtein, O. B. (2005). Dendi: moda, literatura, stil' zhizni.dandy [Dandy: fashion, literature, lifestyle]. Moscow : Novoe literaturnoe obozrenie. [in Russian].

2. Vasil'ev, A. A. (2007). Russkaya moda. 150 let v fotografiyakh [Russian Fashion. 150 years in photographies]. Moscow : Slovo. [in Russian].

3. Vikulina, E. (2011). Reprezentatsiya gendera v sovetskoi fotografii «ottepeli». Sovremennyi diskurs-analiz [Representation of Gender in Soviet "Thaw" Photography. Modern Discourse Analysis]. Electronic Journal, 5. 21-34. [in Russian].

4. Dashkova, T. (2017). Nesluzhebnaya pokhodka: defile v sovetskikh fil'makh ottepeli i zastoya [Unofficial gait: defile in Soviet films of the "thaw" and "stagnation"]. Fashion theory. 4 (46). URL: https://www.nlobooks.ru/magazines/teoriya_ mody/46_tm_4_2017/article/19304 [in Russian].

5. Médnik̄ov, Ya., Litovchenko, V., Sherban', L. (2003). Professiya: model' [Profession — model]. Kyiv: LMU. [in Russian].

6. Nazarenko, M. (2005) Demonstrant odezhdy Viktor Shvets: "Sredi devochek-modelei ya byl, kak petukh v kuryatnike, no ni razu etim ne vospol'zovalsya" [Clothes demonstrator Viktor SHVETS: "Among the girls-models, I was like a rooster in a hen house, but I never used it."]. Gordon Boulevard. 29 (29), URL: http://bulvar.com.ua/gazeta/archive/s29_2770/1637. html (Last accessed: 05.04.2020) [in Russian].

7. Nikolaieva, T. V., Kokorina, H. V. (2018). Tvorcha biohrafiia dyzainera Volodymyra Nesmiiana: mizh pamiattiu ta svobodoiu [Creative biography of designer Volodymyr Nesmyan: between memory and freedom]. Art and design. 3. $132-144$. DOI:10.30857/2617-0272.2018.3.12. URL: http://nbuv.gov.ua/UJRN/artges_2018_3_14 [in Ukrainian].

8. Stepura, M. (2000). Kak stat' model'yu: Uchebnoe posobie [How to Become a Model: A Tutorial]. Rostov-on-Don : Feniks. [in Russian]

9. Ushakin, S. (2002). O muzhe(N)stvennosti: Sbornik statei [About masculinity: A Collection of Articles]. Moscow : Novoe literaturnoe obozrenie. [in Russian].

10. Shchipakina, A. (2009). Moda v SSSR. Sovetskii Kuznetskii [Fashion in the USSR. Soviet Kuznetsky]. Moscow : Slovo. ISBN: 978-5-387-00119-2 [in Russian].

11. Finch + Casta Eyewear prezentuvaly pershyi pokaz $u$ dopovnenii realnosti [Finch + Casta Eyewear presented the first augmented reality show] http://fashionweek.ua/news/ukrainian/finch-casta-eyewear-day-2 [in Ukrainian].

12. Okwodu, J. (2016) 40 Years of Male Models: Tyson Beckford, John Pearson, Tony Spinelli, and Co. Remember Their Glory Days. Vogue.com . URL: https://www.vogue.com/article/male-modeling-icons-40-years (Last accessed: 20.06. 2020) 